\title{
EDITORIAL
}

Prezado leitor,

Um dos muitos termos que vêm sendo assumidos e utilizados na academia tem sido o "publisch or perish". Embora seja originário do meio acadêmico dos Estados Unidos, sua abordagem vem se intensificando no Brasil.

O conceito se refere e induz à compulsão por publicações, em geral intensivas e frequentemente pouco criativas, frequentemente sobre conhecimentos repetitivos e, no máximo, incrementais às literaturas. Raras, portanto, são as produções efetivamente inovadoras, nas lógicas epistêmicas, conceituais e morfológicas.

As pressões institucionais por publicações certamente levam à esta situação, também conhecida pejorativamente como "produtivismo". Neste contexto, cada vez mais, surgem métricas de quantificação da produção científica, que se sofisticam em conceitos e tecnologias, dando origem à estruturas e formatos, como a cienciometria, a bibliometria, a infometria, a webmetria e altimetria, entre outras.

Estas métricas de produção científica e técnica certamente tem levado, tanto ao refinamento da especificação de conteúdos e métodos de abordagem, quanto, e como consequência, ao estrito enquadramento em parâmetros de mensuração estabelecidas pelas bases de demonstração curricular de autores, sendo a mais conhecida atualmente, a plataforma Lattes. Efetivamente, a dinâmica das produções, e de seus respectivos critérios de lançamentos, têm implicado nas necessárias atualizações das bases, aproximando-as da estrutura ORCID. Esta situação revela uma grande comunidade em ação, provocando a efervescência da atividade dos pesquisadores. Em adição, demonstra ainda a necessidade da orientação para a imersão em temas que efetivamente se demonstram inovadores, nas lógicas epistemológica, morfológica e metodológica, no propósito de revelar elementos da realidade de sociedades, organizações e pessoas, especialmente no nosso caso, o Brasil.

É neste contexto que se insere a Revista Gestão \& Tecnologia. A amplitude de seus termos, "gestão" e "tecnologia" demonstra seus propósitos e processos, no sentido de ser um periódico orientado à Ciência da Administração e áreas correlatas, entretanto em uma abordagem plural. Neste sentido, ela vem recebendo submissões e publicando contribuições provenientes de temas, pesquisadores e instituições diversas, consolidando-se como uma rica fonte de conhecimentos em evolução, ou seja, em estado de organização e sistematização.

Com este propósito, a Revista Gestão \& Tecnologia vem sendo descoberta por pesquisadores estrangeiros, que submetem contribuições agregadoras às temáticas variadas que já têm sido publicadas, proporcionando maior enriquecimento epistêmico-teórico-metodológico deste periódico. É com este propósito que esta editoria pretende continuar atuando, tentando contribuir à divulgação e integração de conhecimentos e práticas relevantes para sociedades, organizações e pessoas. Ao mesmo tempo, tentamos contribuir para que se atenue, tanto quanto possível, o simples "publish or perish", ou o "produtivismo radical". Neste propósito, contamos 


\section{(2) G\&T}

com o compromisso e o envolvimento de autores, avaliadores e da equipe editorial, para alavancarmos sempre os conteúdos temáticos deste periódico.

Nesta edição a diversificação teórico-metodológica do periódico se revela e consolida com a publicação de contribuições provenientes de pesquisadores brasileiros procedentes de instituições e regiões variadas, abordando vários temas oportunos, robustos e consistentes à literatura. Adicionalmente, são publicados quatro artigos procedentes de outros países, cujas contribuições situam-se em nível temático e metodológico compatível com os nacionais, reafirmando e consolidando os propósitos editoriais da revista. Neste sentido, este periódico manifesta sua evolução no propósito de aprimoramento da publicação científica, em consonância com os ditames da literatura internacional.

Assim, com estas contribuições à literatura, manifestamos nossos agradecimentos a todos os autores, avaliadores, colaboradores, leitores e, especialmente, à Fundação Pedro Leopoldo, mantenedora deste periódico. Aguardando contribuições na forma de submissões de artigos, de avaliações sérias e consistentes com os propósitos deste periódico, de indicações dela a seus alunos e amigos, assim como de críticas contributivas, renovo os votos de boa leitura e de ótimas reflexões.

José Edson Lara, PhD

Editor-Chefe 